\title{
The Paradox of the Statutory Proofs Theory in the Criminal Ordinance of Saint-Germain-en-Laye
}

Justice was administered in the name of the king by his judges before the French revolution. Criminal decisions were not founded on the judges' own findings. They were theoretically based on a tripartite classification of proofs according to their probative value: the statutory proofs theory.

Is the use of the term "statutory" legitimate to describe such an organization? According to the litteral meaning of the word it originates from the medieval civil and canon law. In Modern Times texts such as the Constitutio Criminalis Carolina expressly referred to it whereas French legislation was much more sparse. We should examinate other sources of law, doctrine and case law to understand the history of this theory. In 1668 Louis XIV. created the parliament of Flanders, a royal court of justice. A study of its criminal sentences will highlight the judges' attitude in front of this classification of proofs.

Justice was administered in the name of the king by his judges before the French revolution. In this inquisitorial system, judges needed evidence to convict a man. What had to be proved? First that a crime has been committed: no corpse, no homicide. Then that the accused was the one who committed the crime.

At that second stage of the investigation, the issue of establishing the guilt was fundamental. Could judges prove guilt by any means? Could they arbitrarily convict an accused with a futile proof? In Modern Times judges' findings could not operate freely: they were framed by a protective system of the accused traditionally called the statutory proofs theory. ${ }^{1}$ Each proof had its own value which was juridically fixed: it was a real safeguard against the judges' arbitrium. This rational system consisted in a classification of proofs according to their probative value. Proofs could even be added in a curious arithmetic ${ }^{2}$

\footnotetext{
${ }^{1}$ LAINGUI, Lebigre, Histoire du droit pénal 110.

2 GILISSEN, Preuve en Europe 760.
}

which has fed doctrinal passions. Thus the full proof was different from the half and lesser value proofs.

The full or manifest proof was sufficient to convince the judge. The accused could be sentenced to the ordinary punishment of the crime he has committed. It was only with such incriminating elements that the judge could sentence him to death. It could result for example from an uncontested written document, from two concordant eyewitnesses (the so-called rare birds of the procedure) or even from strong presumptions. ${ }^{3}$

Then the half proof was a considerable proof but was not sufficient enough to clearly establish the guilt of the accused. It must have been supplemented to become a manifest proof. With the half proof the judge could submit the accused to torture in order to extract his confessions. These confessions combined with the half proof formed a full proof.

\footnotetext{
${ }^{3}$ LAINGUI, LEBIGRE, Histoire du droit pénal 113-114.
} 
Rather than torturing the judge might order a further investigation called "plus amplement informé". ${ }^{4}$ A time limit could go along with this further research of information. The accused might also be released during the investigation or otherwise remain imprisoned. Muyart de Vouglans wrote that the judge should order this kind of investigation "whenever he did not have enough proofs to convict and not enough to discharge" ${ }^{\prime 5}$ In practice, we notice that the judge sometimes pronounced a punishment on the basis of a half proof: it is then less important than the usual punishment of the crime. This is called a pro modo probationum conviction.

Finally, there were other clues that allowed judges to take decrees to call in or to arrest the accused and thus investigate to seek other incriminating evidence.

During the famous Calas case Voltaire openly criticized this theory, satirising it: "The Parliament of Toulouse has a singular custom concerning proof by witnesses. Somewhere else, we admit half proofs which actually are just doubts: because we know there is no half-truth; but in Toulouse we accept quarters and eighths of proofs. We can consider there, for example, a hearsay as a quarter, another vaguer hearsay as eighth; thus eight rumors which are just an echo of an unfounded noise may become a full proof; and it is almost on this principle that Jean Calas was sentenced to the wheel. Roman laws required "luce meridiana clariores proofs". 6

Lanjuinais formulated a similar criticism: "What about this singular case law which horrifies, admitting quarters, thirds, sixths of proofs; with six hearsays on one side, three on the other, and four quarters of presumptions, we form three full proofs and on this beautiful demonstration, a man is sentenced to the wheel without mercy.

\footnotetext{
4 It could be translated by "more fully informed"

${ }^{5}$ MUYART DE VOUGLANS, Institutes au droit criminel 362 (translation).

6 VOLTAire, Euvres complètes 96 (translation).
}

Your Majesty is too enlightened not to recognize that from all probabilities combined together it would never result a certainty; what is called a half proof is not a proof, since there has never been any half proof: because something is proven or it is not. There is no medium. Hundred thousand united suspicions can no more make a proof, that one hundred thousand zeros cannot become a number."7

The statutory proofs theory was in Modern Times the cornerstone of the judicial practice but this name was paradoxical. Indeed French legislation never gave any real value to this classification. So can we legitimately use the term "statutory" to describe it? (I) The criminal ordinance of 1670 even provided a way to override the statutory proofs theory concerning torture (II).

\section{A statutory classification of proofs?}

Three famous ordinances reformed the criminal procedure in France in Modern Times. The first two texts, those of 1498 and 1539, contained no provisions concerning the strength of proofs. We have to wait the ordinance of Saint-Germain-enLaye in 1670 to see two implicit allusions to the strength of proofs. This text incorporated and completed the two previous ones.

Art. 1 of title XIX of the ordinance of 1670 required three cumulative conditions to use torture. ${ }^{8}$ First the crime must have been punishable by death. Then the materiality of the crime must have been established. Finally a "considerable proof" against the accused must have been reported: it was the famous half proof although the text did not call it so. The ordinance using the words "considerable proof" without any

\footnotetext{
7 LANJUINAIS, Monarque accompli 317 (translation). 8 IsAMBERT u.a., Recueil général XVIII, 412 (translation).
} 
further details gave to judges the full appreciation of it. Serpillon did not hesitate to write that "the difficulty is to know which proofs are considerable; those that may be considerable for a vagabond or other of ill fame shall not be considered in the same way when the accused is domiciled and has a good reputation [...] they depend on the location, time, people's quality and on an infinity of other circumstances". 9

The parliament of Flanders was a royal court created by Louis XIV. in 1668. It was mainly an appellate court and its decisions highlighted the judges' sovereign appreciation concerning proofs. In a study based on the criminal case law of this court from 1668 to 1720, on 2509 decisions eleven cases were found in which parliamentarians nullified a torture on appeal and sentenced directly the convicted to death. ${ }^{10}$ It means that the same proof was on appeal considered as a full proof but not at first instance. This was an example of the expression of the judges' arbitrium. The opposite is nevertheless not valid: no decisions ordering torture on appeal instead of death penalty were found among the recounts of the decisions.

Art. 5 of Title XXV required that "criminal trials may be prepared and judged although there is no information yet; and if also there is a sufficient proof thanks to interrogations and authentic documents or documents recognized by the

\footnotetext{
${ }^{9}$ MERLIN, Répertoire universel XIII, 19 (translation). ${ }^{10}$ A.D.N., 8B2/761 fol. 89v-90r (Félix Wantier, 30. 4. 1683); A.D.N., 8B2/761 fol. 139v $-140^{\mathrm{r}}$ (Eloy Lefebvre, 15. 5. 1686); A.D.N., 8B2/763 fol. 179 $-179^{\mathrm{v}}$ (André Cardon, 17.10.1689); A.D.N., 8B2/767 fol. 288 ${ }^{\mathrm{r}}-289^{\mathrm{r}}$ (Nicolas Jacquart, 17. 6. 1698); A.D.N., 8B2/767 fol. 308 $-309^{\mathrm{r}}$ (George Houplin, 10. 9. 1698); A.D.N., 8B2/770 fol. 21 ${ }^{\mathrm{v}}-22^{\mathrm{r}}$ (Florent Crucque et Nicolas Delebecque, 30. 6. 1699); A.D.N., 8B2/770 fol. 169v170r (Jeanne Puyt, 6. 4. 1702); A.D.N., 8B2/772 fol. 15v (Bernard Torsaquier, 25. 8. 1703); A.D.N., 8B2/772 fol. $80^{\mathrm{r}}-81^{\mathrm{r}} \quad$ (Pierre Wallart, 30.4.1706); A.D.N., 8B2/773 fol. 125 $125 \mathrm{v}$ (Jean-Pierre Corbehem, 12.10.1717) ; A.D.N., 8B2/774 fol. 11 ${ }^{\mathrm{r}}-12^{\mathrm{r}}$ (Noël Gulo et Germain Sannage, 13. 7. 1719).
}

accused, and other presumptions and circumstances of the trial". ${ }^{11}$ The chosen terms concerning the strength of proofs, "a sufficient proof", are one more time sparse and can be freely interpreted by judges.

Similar terms are used in the Charles V.'s Constitutio Criminalis Carolina in 1532 for the Holy Roman Empire. In the sixth article we find the word "sufficient": "When someone is suspected of a crime through common repute, or is notorious on account of other credible indication, and consequently has been arrested by the authorities acting ex officio, he shall at first not be examined under torture unless there is credibly established legally sufficient and consequently suitable indication connecting him to the said crime." 12

Art. 18 to 44 of the Carolina dealt with the strength of proofs: their values were explained crime after crime using examples to guide the judge with no will to be exhaustive. Proofs must have been rational, Art. 21 required that "no one shall be gaoled or examined under torture upon indication of those who purport to be able to soothsay through sorcery or other artifice. Rather these pretended soothsayers and complainants shall in consequence be punished". ${ }^{13}$

Unlike the French ordinance of 1670, concrete examples of sufficient evidence to torture were given, first generally then specially. Generally Art. 29 provided that "when someone in the committing of the crime loses something or lets it fall or be left behind, so that it can afterwards be found and determined to have belonged to the criminal, examination under torture is appropriate in order to discover who had the thing immediately before it was lost unless he interposes something to the contrary, and were it to turn out or be established, the said suspicion

\footnotetext{
${ }^{11}$ ISAMBERT u.a., Recueil général XVIII, 415 (translation).

12 LANGBein, Prosecuting crime 269.

${ }^{13}$ Langbein, Prosecuting crime 273.
} 
would thereby be resolved, in which case this excuse shall first be investigated, before any examination under torture". ${ }^{14}$ Provisions concerning torture used explicitly the terms "half proof". Thus we can read in Art. 30 that "A half proof, as when someone thoroughly proves the essential element of the crime with a single good and upright witness that is and is called a half proof and such a half proof also constitutes a legally sufficient indication of suspicion of the crime". ${ }^{15}$ Specially, sufficient evidence to order torture was detailed for several crimes: the text gave a list of evidence that allowed to torture those who were accused of being murderers (Art. 33-34), children killers (Art. 35-36), poisoners (Art. 37), thieves (Art. 38-40, 43), arsonists (Art. 41), traitors (Art. 42), or sorcerers (Art. 44). ${ }^{16}$

With such a text we can legitimately talk about a statutory classification of proofs. It is not possible in France on the basis of the three criminal ordinances. Therefore using the term "statutory" to describe the judicial practice seems to be inaccurate. The only way to legitimize the use of this term is to consider it as a reference made by doctrine to medieval civil and canon law. ${ }^{17}$ Roman and canon law have indeed established rules of proofs. In the third century, under Diocletian, we already find a tendency towards to the regulation of proofs. Then this tendency grew and many provisions regarding the strength of proofs were part of the corpus juris civilis. 18

Paradoxically legislation did not grant a real value to this hierarchy of proofs. It even accorded to the judge a way to override it.

\footnotetext{
${ }^{14}$ LANGBEIN, Prosecuting crime 275.

15 Ibid.

${ }^{16}$ LANGBeIN, Prosecuting crime 276-279.

${ }^{17}$ LAINGUi, Lebigre, Histoire du droit pénal 111.

18 LeVY, Hiérarchie des Preuves 11.
}

\section{A deconstruction of the statutory proofs theory: the consecration of the reserve of evidence}

Judges could order torture when serious evidence was gathered against the accused but was insufficient to fully establish his guilt. The aim was to extract his confession by violence. This confession supplemented the body of evidence and allowed judges to pronounce the death sentence.

Formerly if the accused did not confess under torture the procedure ended. Evidence that had been the foundation of torture was purged and no punishment could then be pronounced anymore: the accused must have been released. ${ }^{19}$ This practice was even consecrated in the ordinance of Villers-Cotterêt in 1539: Art. 164 explained that "if while using question or torture nothing can be obtained against the accused, so that there is no material to convict him: we want him to be granted absolution $\{\ldots . .]^{\prime \prime} .{ }^{20}$ All the more it was impossible to convict a man who has nothing confessed under torture on the basis of a half proof.

Some are more robust than others and those who were able to endure the torments of torture without confessing anything were released while those who surrendered under the pain were sentenced to death. Serpillon even reported a ploy used by prisoners about to be tortured: a soap which had the property of dilinishing the reactions of the nerve-system. ${ }^{21}$ The practice evolved outside the law to prevent the most resistant criminals from being unpunished.

The use of torture with a mechanism called "reserve of evidence" appeared in the XVI ${ }^{\text {th }}$ century in the senate of Milan and the parliament of

\footnotetext{
${ }^{19}$ LAINGUI, LebigRe, Histoire du droit pénal 120.

20 ISAMBERT u.a., Recueil général XII, 634 (translation).

${ }^{21}$ DuRAND, Que nul n'entre 41-42.
} 
Paris. ${ }^{22}$ The judgment then ordering torture added the proviso that the evidence would remain reserved. We often find in this case the Latin formulation "manentibus indiciis". The gathered evidence would not be purged anymore even if the accused persisted in denying under torture. His judges would still have the possibility of sentencing him to any punishment lesser than death. As Noger wrote, "it would be abnormal not to convict somebody estimated guilty but robust enough!". ${ }^{23}$

This practice has been developed by courts, spread and was finally consecrated by the criminal ordinance of 1670. Art. 2 of Title XIX of this ordinance required that "Judges can also decide that, in spite of the sentence ordering torture, evidence will fully remain in order to sentence the accused to all kinds of pecuniary or afflictive punishments, excepting death penalty, which the accused who suffered torture without confessing cannot be sentenced to, unless new evidence occur since the torture". ${ }^{24}$

The reserve of evidence allowed the judge to impose any punishment except death. This evolution appeared to be a statutory way to circumvent impunity: it allowed the judge to convict on the basis of an imperfect proof. This was called a pro modo probationum sentence. A step was taken towards the expression of the judge's arbitrium.

According to the ordinance the reserve of evidence was just a possibility given to judges. In the parliament of Flanders its use was almost systematic. ${ }^{25}$ If the trial judges ordered torture without the reserve of evidence the parliament would invalidate the decision and order the use of the reserve. ${ }^{26}$ Two cases however seem curi-

\footnotetext{
22 LAINGUI, LeBIGRE, Histoire du droit pénal 121.

${ }^{23}$ DURAND, Arbitraire du juge 154 (translation).

${ }^{24}$ ISAMBERT u.a., Recueil général XVIII, 412 (translation).

${ }^{25}$ LE MARC'HADOUR, Question préparatoire 763.

${ }^{26}$ A.D.N. 8B2/763 fol. 29v (Marie Pollet, 28. 1. 1682);

A.D.N. 8B2/761 fol. 125r (Josse Damman, 10. 7. 1685);
}

ous: the cases Crespin Dorémieux ${ }^{27}$ and François Veuwarde. ${ }^{28}$ In 1684 Crespin Doresmieux was sentenced by the judges of Lille to be tortured for unknown facts. The sentence provided a reserve of evidence. The Flemish parliamentarians partially overturned the judgment on appeal: the accused would be submitted to torture but they removed the reserve of evidence. Crespin Dorémieux then disappeared from the criminal archives of the institution. We find him again twenty years later when he was arrested for having stolen money. He was sentenced in 1704 to be banished for five years from the region of Lille. ${ }^{29}$ We can conclude that he did not confess anything under torture in 1684.

François Veuwarde lived the same situation in 1693: the judges of the city of Merris ordered his submission to torture. The parliament of Flanders removed one more time the reserve of evidence on appeal. Nevertheless the accused confessed under torture that he murdered his pregnant wife. He killed her with a gun through a hole he made in the wall of their room. Among all the studied decisions between 1668 and 1720 these two cases are the only ones in which judges removed the reserve of evidence. The reason remains today a real mystery.

The statutory proofs theory was paradoxically not consecrated by the ordinances which organized the criminal procedure in France in Modern Times. Under the sway of this legislation, far from the precision of Charles V.'s Carolina,

A.D.N. 8B2/766 fol. $46^{\mathrm{r}}-46^{\mathrm{v}}$ (Daniel-Louis Sandoz, 10. 9. 1691); $8 \mathrm{~B} 2 / 767$ fol. $67^{\mathrm{v}}-68^{\mathrm{r}}$ (Charles Coulon, 30. 3. 1694); A.D.N. 8B2/770 fol. $148^{\mathrm{v}}-149^{\mathrm{r}}$ (MarieJeanne Verbeck, 22.10.1701); A.D.N. 8B2/773 fol. $145^{\mathrm{v}}-146^{\mathrm{r}}$ (Guillaume Winoc de Ryche, 13. 8. 1718).

${ }^{27}$ A.D.N. 8B2/761 fol.104v (Crespin Dorémieux, 14. 4. 1684).

28 A.D.N. 8B2/767 fol. 49v-50 (François Veuwarde, 18. 11. 1693).

${ }^{29}$ A.D.N. 8B2/772 fol. 28 ${ }^{\mathrm{r}}$ (Crespin Dorémieux, 10. 4. 1704). 
judges seemed to be free to appreciate the evidence, perhaps even arbitrarily. And since any appreciation of the evidence seems to be arbitrary, in la Théorie des lois criminelles Brissot gives us this advice: "Do not search the art of proofs estimation, it is the philosopher's stone of criminal case law. It is impossible to establish fixed and certain rules to distinguish a full proof from an incomplete one, convincing clues form uncertain ones". He even demonstrated the uselessness of the classification of proofs, arguing that "The torch of reason, the calculation of the moralist, the voice of humanity, are the only guides that the judge must follow in this dark labyrinth". ${ }^{30}$

\section{Korrespondenz:}

Sébastien Dhalluin

19 rue du Lieutenant Colpin, 59000 Lille, France sebastien.dhalluin@univ-lille2.fr

\section{Abkürzung:}

A.D.N. Archives départementales du Nord

\section{Literatur:}

Jacques-Pierre BRISSOT, Théorie des lois criminelles, Bd. 2 (Berlin 1781).

John GILISSEN, La preuve en Europe du XVIe au début du XIXe siècle, in: La preuve, quatrième partie, période contemporaine (= Recueil de la société Jean Bodin pour l'histoire comparative des institutions 19, Bruxelles 1963).

Bernard DURAND, Arbitraire du juge et droit de la torture : l'exemple du Conseil Souverain de Roussillon (1660-1790) (= Recueil de mémoires et travaux publié par la Société d'histoire du droit et des institutions des anciens pays de droit écrit 10, Montpellier 1979).

Bernard DURAND, Que nul n'entre ici s'il n'est géomètre (Lille 2011).

François-André ISAMBERT u.a., Recueil général des anciennes lois françaises depuis 420 jusqu'à la révolution de 1789, Bd. 18 (Paris 1829).

André LAINGUI, Arlette Lebigre, Histoire du droit pénal, Bd. 2 (Cujas 1979).

John-H. LANGBEIN, Prosecuting crime in the Renaissance: England, Germany, France (New Jersey2005).

Jean-Denis LANJUINAIS, Le Monarque accompli, ou prodiges de bonté, de savoir et de sagesse qui font l'éloge de Sa Majesté impériale Joseph II et qui rendent cet auguste Monarque si précieux à l'humanité, Bd. 1 (Lausanne 1774).

Tanguy LE MARC'HADOUR, La question préparatoire dans les Pays-Bas français" in: Bernard DuRAND (Hg.), La torture judiciaire, Bd. 2 (Lille 2002), 763.

Jean-Philippe LEVY, La hiérarchie des preuves dans le droit savant du Moyen-Age depuis la renaissance du droit romain jusqu'à la fin du XIVe siècle (Paris 1939).

Philippe-Antoine MERLIN, Répertoire universel et raisonné de jurisprudence, $\mathrm{Bd} .13$ (Paris 1827).

Pierre-François MuYART DE VOUGLANS, Institutes au droit criminel (Paris 1757).

Voltaire, Euvres complètes de Voltaire avec des remarques et des notes historiques, scientifiques et littéraires, Bd. 2 (Paris 1827).

\footnotetext{
30 BRISSOT, Théorie des lois criminelles 87 (translation).
} 